\title{
Analysis of the Effect of Macro Economic Indicators and Dow Jones Index on IDX Composite in Indonesia Stock Exchange
}

\author{
Isra Rafika Sihombing ${ }^{1}$, Irsad ${ }^{2}$, Ahmad Albar Tanjung ${ }^{3}$ \\ ${ }^{1}$ Posgraduate Students, ${ }^{2,3}$ Postgraduate Lecturer, \\ Faculty of Economics and Business, Department of Economics, Universitas Sumatera Utara, Indonesia
}

Corresponding Author: Isra Rafika Sihombing

\begin{abstract}
Study aims to analyze the macroeconomic effect of the Dow Jones index on IDX Composite on the Indonesia Stock Exchange. The variables used in the macro economy are inflation, kurs, $S B I$ rate, FED rate. Another variable is the Dow Jones index. This study uses quarterly secondary data from 2010 to 2020. The data analysis model uses the Autoregressive Distributed Lag (ARDL) approach. The results of the ARDL model analysis show that in the long term inflation, kurs, and FED rate has a negative and insignificant effect on the IDX Composite, SBI rate variable has a positive and not significant effect on the IDX Composite, the Dow Jones index variable has a positive and no significant effect on the IDX Composite significant to the IDX Composite. In the short term, inflation has a negative and insignificant effect on the IDX Composite, kurs has a negative and significant effect on the IDX Composite, SBI rate has a positive and insignificant effect on the IDX Composite, FED rate and the Dow Jones index have a positive and significant effect on the IDX Composite.
\end{abstract}

Keywords: IDX Composite, Inflation, Kurs, SBI Rate, FED Rate, Dow Jones index.

\section{INTRODUCTION}

The capital market has two functions, namely the economy and financial functions. The capital market is one of the alternative investment options that benefit investors optimally (Tandelilin, 2010: 2). The investment itself can be interpreted as an activity of putting funds in one or more of the assets owned by an investor with a certain period of time with the goal of profit (return) as well as the increase in the value of the investment itself. Investing through the capital market is one of the investments that are most in demand by every country, due to its role can be a booster for the resistance economy in a state including the source of the state income used for development funding, run the wheels of the economy and attract foreign investors into the country. If a country wants both last a long time in the country, then the government is required to keep the situation and political conditions and a stable currency, and always pay attention to economic growth (Pasaribu et al 2008:1).

The capital market itself is a container to buy and sell all instruments in the long term. The instruments traded in perjual on capital markets one of them is stock. The stock price is the value of equity securities that reflect the wealth of the company that issued the shares, where the changes and the fluctuations are determined by forces of demand and supply that occurs in the stock market or secondary market (Princess, 2017: 11). Before investing investors should be looking for and have information related to the price of the stock so that it can decide whether the stock is worth to be selected to invest or not. The reason is because the price of the stock is 
always fluctuating and has the nature of high risk high return.

Stock trading has a cycle up and down and caused the stock price to continue to move. The movement of stock prices is an important thing that should be followed by an investor before investing, because the movement can assess your performance and achievements that took place by the issuer. The information described above aims to see and monitor the stock price through the composite stock price index. The composite stock price index informs the movement of stock prices in general, a company incorporated in the stock exchange. Therefore, through the movement of the composite stock price, investors can monitor the condition of the market, whether it is experiencing a rise or vice versa.

Table 1: Lists The World
\begin{tabular}{|c|l|l|c|c|c|}
\hline No & Name Index & Negara & Previous close & Open & Acquisition Year \\
\hline 1 & Dow Jones & Amerika Serikat & $32.981,55$ & $33.054,58$ & $50,48 \%$ \\
\hline 2 & Nikkei 225 & Jepang & $29.388,87$ & $29.441,91$ & $56,09 \%$ \\
\hline 3 & CAC 40 & Prancis & $6.067,23$ & $6.079,67$ & $38,01 \%$ \\
\hline 4 & KOSPI & Korea Selatan & $3.061,42$ & $3.073,77$ & $75,44 \%$ \\
\hline 5 & Hang Seng & Hong Kong & 28,927 & 28.618 & $20,18 \%$ \\
\hline 6 & KLCI & Malaysia & $1.573,51$ & $1.579,97$ & $17,13 \%$ \\
\hline 7 & FTSE Singapore & Singapura & 328,46 & 326,16 & $27,15 \%$ \\
\hline 8 & Nifty 50 & India & $14.690,7$ & $14.79,4$ & $70,87 \%$ \\
\hline 9 & HNX 30 & Vietnam & 415,47 & 415,64 & $151,12 \%$ \\
\hline 10 & IDX Composite & Indonesia & $5.985,52$ & $5.988,02$ & $31,87 \%$ \\
\hline
\end{tabular}

In Table 1 describes the index of global stocks from 10 countries. The shares of most large acquisition annually comes from neraga Vietnam, namely the HNX index of 30 that is equal to $151,12 \%$. Focus on the state of Southeast Asia, Indonesia showed a gauge of the cost is not too small that is equal to $31,87 \%$ of the IDX
Composite or in the know with JCI, compared to the Singapore show numbers $27,15 \%$ and the Malaysia show the numbers for $17.13 \%$. When compared with countries outside of south east Asia IHSG, Indonesia is still relatively small. In table 2 described the performance of the IHSG the last 10 years.

Table 2: The performance of the composite Stock Price IHSG 10 Years Last

\begin{tabular}{|c|c|c|c|}
\hline Year & IHSG The End Of The Year & The Acquisition Of The Annual & Accumulated Acquisition \\
\hline 2010 & $3.703,51$ & Initial value & Initial value \\
\hline 2011 & $3.821,99$ & $3,20 \%$ & $3,20 \%$ \\
\hline 2012 & $4.316,69$ & $12,94 \%$ & $16,56 \%$ \\
\hline 2013 & $4.274,18$ & $-0,98 \%$ & $15,41 \%$ \\
\hline 2014 & $5.226,95$ & $22,29 \%$ & $41,14 \%$ \\
\hline 2015 & $4.593,01$ & $-12,13 \%$ & $24,02 \%$ \\
\hline 2016 & $5.296,71$ & $15,32 \%$ & $43,02 \%$ \\
\hline 2017 & $6.355,65$ & $19,99 \%$ & $71,61 \%$ \\
\hline 2018 & $6.194,50$ & $-2,54 \%$ & $67,26 \%$ \\
\hline 2019 & $6.299,54$ & $1,70 \%$ & $70,10 \%$ \\
\hline 2020 & $5.988,02$ & $-5,09 \%$ & $61,44 \%$ \\
\hline \multicolumn{2}{|r|}{ Performance IHSG 10 Years Annualized : 4,91\% } \\
\hline
\end{tabular}

Source: Indonesia stock Exchange (www.idx.co.id)

Based on data obtained from the composite stock price index in Indonesia stock Exchange, the results obtained when viewed from the trend line each year shows a tendency to experience up and down. Judging from the years 2010-2012 composite stock price index continued to rise in the position of $3.703,15-4.316,69$ but in 2013, a decline that is to be $4.274,18$. Then in 2014 climbed back into 5.226,95 and 2015 decreased back and up on the 2020 re decreased to 5.979,07. More details can be seen on the image of the chart, as follows: 


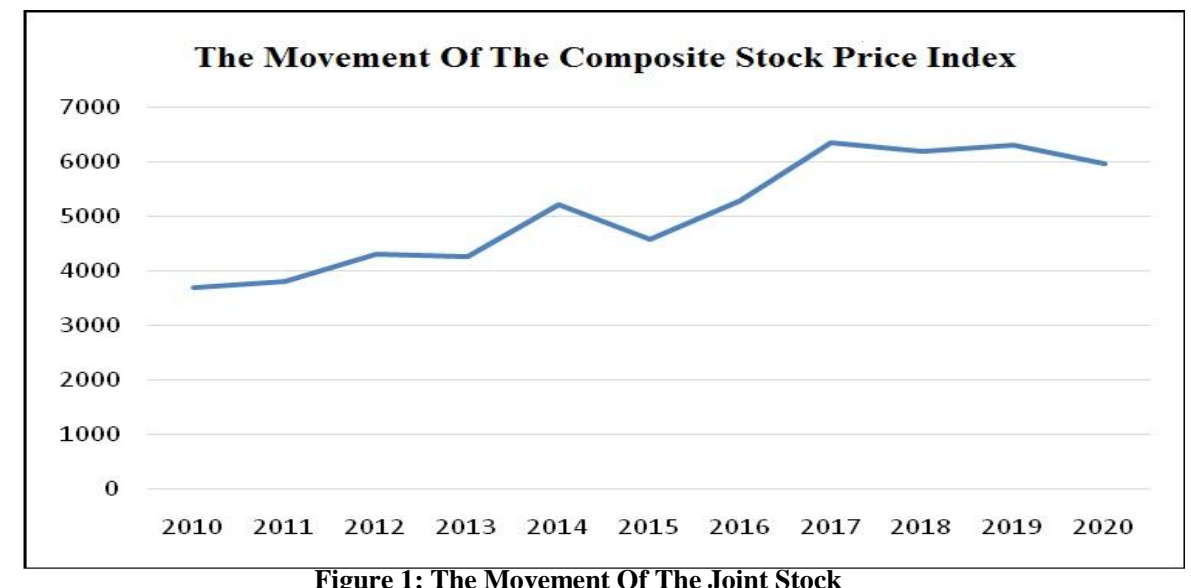

Source: Yahoo finance

The movement of the composite Stock Price Index is very sensitive to changes in the fundamentals of the economy and changes in expectations about future prospects (Kusuma and Badjra, 2016:2). Fundamental analysis stock includes: (1) Analysis of financial aspects, namely: the book value of the shares, the earnings per share, book value of equity and the ratio of expenditure; (2) Analysis of the annual report of the company including: outline the philosophy of the company, reports the company's operations, financial information, records of the foot and a written statement of the auditor. It should be understood that the movement of the composite stock price index also caused by several factors including macro economic factors and indices abroad. Investors should be wise in making decisions before investing so that the investment is profitable. Changes in macroeconomic variables and the abroad gives a big influence to the capital market (Aditya, 2018: 287).

Changes in the macro economy in the country of Indonesia will certainly affect the national economy as well as the entire industry. For example, high inflation and the weakening of the rupiah will make a lot of industry experience shaking, production decreased due to the prices of raw materials continue to rise resulting in a decrease of the rate of profit. The declining rate of profit would necessarily impact on the decline in the stock price in the industry because of the dividends to be received by the holder stock will decline; so many investors will withdraw their investments. Rising interest rates will make investors more interested to invest in the form of savings in the bank rather than investing in the capital market. The stock price in the industry will also have an impact on the decline in the value of the composite stock price IHSG in Stock exchange Indonesia. The macro economy does not affect the company's performance in real time but rather slowly and in a long period of time. Instead of stock prices will be affected immediately by changes in the macro economic factors such as investors is quick to react. Changes in the macro economy that happens, investors will take into account the impact of both positive and negative towards the company's performance the next few years, then take the decision to buy, sell or hold the shares concerned (Samsul, 2006: 335). Therefore the stock prices more quickly adjust to changes in macro variables of the economy rather than performance of the company concerned.

The activity of stock prices are influenced by macro economic composed of inflation, interest rates, exchange rates, economic growth rates, the price of fuel oil in the international market, and index stocks regional (Samsul, 2006: 335). Then the activity of the stock price can be seen and measured by the indicators of the composite stock price index. Many factors can affect the rise and fall of the stock performance. One is the macro economic factors such as 
inflation and exchange rates. Meanwhile, global economic conditions that affect the stock one is interest rates, The FED and the Dow Jones (Sutanto, 2013:3).

A company's stock price can also be influenced by the state of the internal economy of a country, one of which is inflation. Inflation can be interpreted as a symptom of the rise in the price of goods constantly. Stable inflation as well as restrained will be able to attract investors to invest their funds in the capital market, so that the volume of trading in the capital market will increase, and will be followed by the strengthening of the composite stock price index is a benchmark stock market performance. Conditions at the time the country experienced a decline with low economic growth, the more experience a negative economic growth is a difficult thing to expect of the capital market could develop. Capital market it is difficult to develop at a time when economic conditions are currently experiencing distortion in the form of inflation on a scale that high. This happens because such conditions lead to the investment climate is no longer attractive to investors, so that investors tend to withdraw funds back their invested in the form of stock and switch to other forms of investment which resulted in activity in the capital market experienced a decline. These conditions prompted a decline in the performance of business entities and investment, which will be responded to by the investors in the capital markets which will eventually affect the price of the stock market.

Inflation is the percentage annual increase in the general level of prices measured by the consumer price index. High inflation cause the increase in the price of the goods, so a decline in purchasing power which resulted in the company's earnings will also go down, It will lose the interest of investors, resulting in the decline of the stock market.

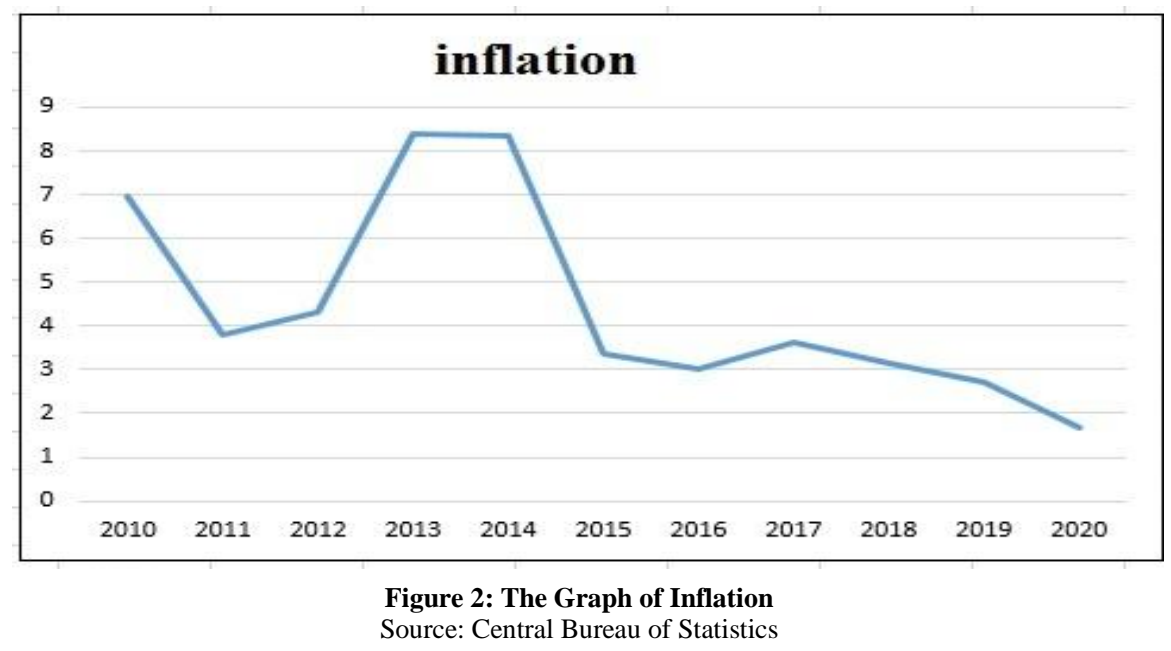

Seen from figure 2 describes the rate of inflation from 2010 to 2020. When viewed overall inflation has decreased, inflation decreased in 2011 from the previous year and increased from the year 2012, in 2013, the increase is quite large, namely $8,38 \%$, so it cause the poverty rate increased. 2014 inflation is still high is not much different with the previous year but slightly lower. In the year 2015 to 2016 decreased, and had climbed back in 2017, and from 2018 until 2020, inflation fell to figure 1.68 percent. There exists the possibility of the food supply is adequate, social restrictions and falling demand effects of implementation restrictions on large-scale social.

The exchange rate or exchange rate is the price of a currency against other currencies. Exchange rates play an important role in the economy. The exchange rate used in the business activity 
carried out by individuals, companies and countries. The weakening of the exchange rate of a country's currency will have a negative influence on the economy and capital markets. The rise and fall of the value of foreign exchange rates to become one of the impacts for the overall business world, the foreign exchange rate reflecting the balance of demand and supply of currency of the state against foreign currencies. The exchange rates referred to in this research is the Rupiah exchange rate against the U.S. Dollar (EUR/USD). Shares on the stock exchange, the investment in foreign exchange in this case are the dollar (USD). If the current exchange rate of the dollar was weaker against the rupiah and can be predicted to be strengthened in the future, and also when the alternative investment other less promising, then the investor may be inclined will invest the funds in the form of currency dollar with the expectation that when the dollar exchange rate against rupiah increased again he will sell it back to the in the form of rupiah, so as to obtain a gain from foreign exchange. In addition to as an alternative investment, the movement of that currency will also have an impact on the import export trade of goods and services related to corporate issuers. These conditions will ultimately have an impact on the activity of the Capital Market, and will further result in the movement of the IHSG on the stock exchange.

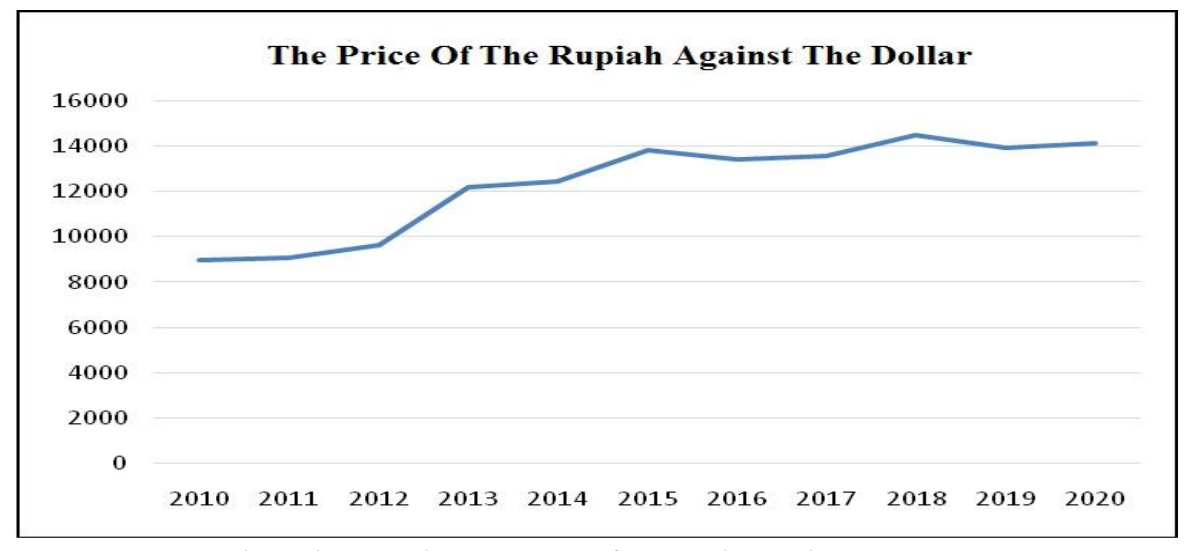

Figure 3: The Price Movement of the Rupiah against the Dollar Source: finance.yahoo

Figure 3 describes the movement of the exchange value of the Dollar against the rupiah, where the price of the Rupiah against the Dollar if the viewed image on the whole has increased significantly. The price of the Rupiah against the Dollar in the year 2010 amounted 8991, in the year, on average, experienced an appreciation of $3.8 \%$ from the previous year. From the last 11 years the price of the Rupiah against the Dollar high in the year 2018, that is, 14481, driver of the depreciation of the Rupiah is the factor capital outflow and coupled with the increase in the level of The FED's benchmark rate twice in the year 2018. However, there are positive factors, with the state Budget the healthy and credible, so that we can feedback the trust of the international strong enough about the fundamentals of the Indonesian economy. Of course there are also negative impacts should be aware that the uncertainty of the market, trade policy the U.S. against its partners trading (Srimuliani: 2018)

SBI interest rate is also one of the variables which can affect the price of the stock. In general, the mechanism is that the SBI interest rate can affect the interest rates on deposits, which is one of the alternatives for investors to take a decision to invest. If the interest rate of SBI is set to increase, investors will get greater results over the deposit rate that is implanted so that investors will tend to deposit their capital than investing in stocks. This has resulted in investment in the capital market will be getting down and eventually result in the weakening of the composite stock price 
index in theory, the interest rate and the stock price has a negative association (Tandelilin, 2010). The interest rate that is too high will affect the present value cash flow of the company, so the opportunities the investment will not be interesting anymore. High interest rates will also increase the cost of capital that will be borne by the company and will also cause a return that is implied investor of an investment will increase.

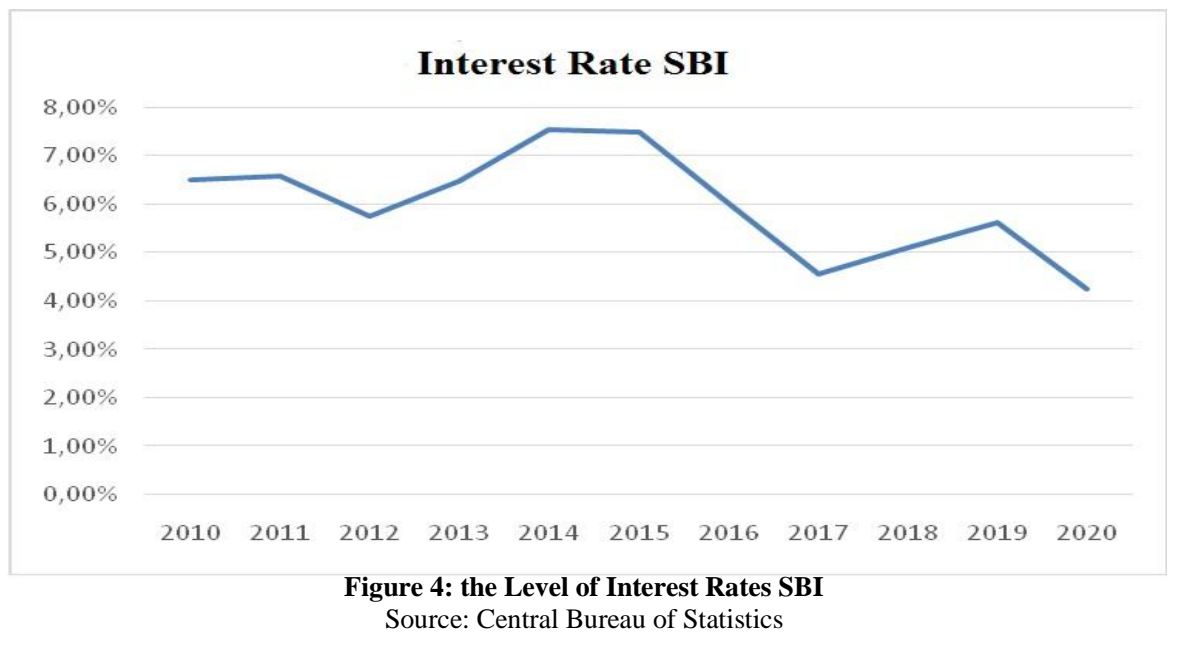

Seen from figure 4 describes the rate of SBI interest rate from 2010 to 2020 . The overall level of interest rates on SBI show a decline, the rate of SBI interest rate decreased from the previous year in the year 2012, the Central Bank lowered interest rates of SBI in the foreground to the background by core inflation is still benign and global economic conditions are uncertain. In 2013 and 2014 the rate of SBI interest rate rise, the Central Bank's goal of raising the SBI is to strengthen liquidity management and increase the effectiveness of the operation of monetary and financial market deepening. The adjustment is part of the next step of Bank Indonesia in the control of inflation, rupiah exchange rate stability as well as efforts to decrease the current account deficit. SBI interest rate 11 year low last year of 2020 of $4.50 \%$, the decision is consistent with its inflation forecast to remain low, the stability of the external wakefulness, as well as efforts to support the economic recovery (bi.go.id).

The factors that affect the IHSG not only from domestic, but also there are factors that come from outside Indonesia such as the foreign interest rate and the stock of foreign affairs. Some interest rates abroad and the stock of foreign affairs that there, it is estimated interest rate of the United States and the United States stock that has the most powerful influence. Because the United States is a developed country so that his economic policies have an influence on the countries in the world, including Indonesia. Interest of the United States or often known benchmark interest rates The FED important to note its movement because it is able to affect the IHSG. Interest rates The FED itself is a number the tribe of interest set by the Central Bank of the United States where its function is as a benchmark for banks and financial institutions in the United States. Interest rates The FED has the responsibility to determine and control the level of circulation of USD as a form of maintaining monetary stability or the price through the levels of the money supply. USD is the currency for all members of the International Monetary Fund (IMF) which has been established since 29 July 1996, and is the countries that are members of the IMF. Therefore, any policy issued by the Central Bank of the United States responded positively and negatively by the market participants around the world including Indonesia. Under this growth rate in The FED's benchmark rate from 2010 to 2020. 


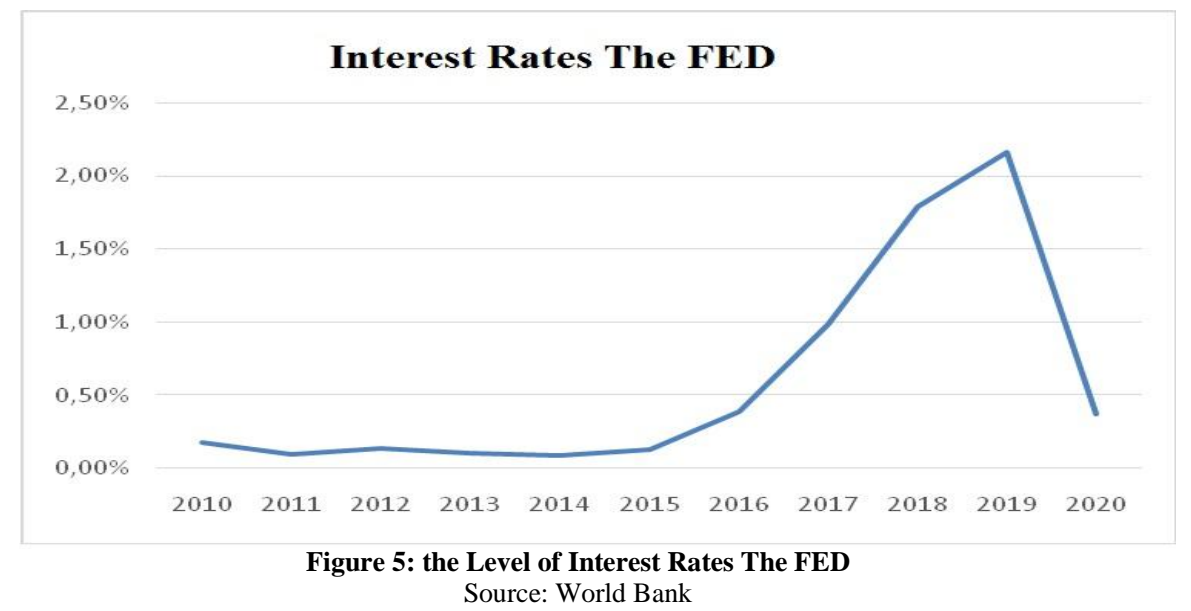

Based on data obtained from the world bank, data on the 2011 level of The FED's benchmark rate decreased from the previous year from $0.18 \%$ to 0.10 percent, this happens because the Central Bank of the United States to maintain low interest rates, i.e. the range of 0 percent to 0.25 percent. The goal is the recovery of the U.S. economy. The level of The FED's benchmark rate is the highest in the year 2019 at $2.16 \%$, it is in the foreground to the background by the trade war the United states with China, so that the slowing global economy and low inflation (openigo.com).

Not only that, the movement of the capital market of today's world are integrated. The integration of the capital market of the world and globalization are closely related. The Model of the global economy more open and abolish the boundaries between countries, and also supported by advanced technology makes the investor is free to do both whenever and wherever. Capital markets are often used as a benchmark for investors generally is the domestic capital market precisely developed countries. Where the country has a stock exchange tend to berkapitalis high and the liquid. Developed countries such has a major influence on the capital market of the world (Mansur, 2005). Capital market is the largest in the world is located in the city of New York, United States. Eun and Shim (in Khadija, 2011) stated capital market the United States is that the capital market is the most influential, until it can affect the movement of the capital market to another. the Dow Jones is an index measuring equity market performance of the United States, and is the average index of the biggest stocks in the world therefore the movement of the Dow Jones can affect almost the entire world stock indices, including the IHSG. The influence of the Dow Jones IHSG estimated positive in the sense of rise in the Dow Jones will lead to a rise in the IHSG in the Indonesia stock Exchange it is caused by the presence of positive sentiment from investors to the economic conditions of the world (Hidayati, 2017).

The Dow Jones often be an indicator of investors in observing the state of the stock indices of other countries because the Dow Jones can describe how the performance of the economy of the United States that can affect the economy of the country that has relations with the United States. Companies listed on the Dow Jones are large companies such as Citigroup, Exxon Mobil, and Coca Cola's operations in Indonesia. The movement of the bullish trend of the Dow Jones showed in general the American economy is in good condition. Good performance of the economy in America, will encourage the Indonesian economy from exports or foreign investment, either directly or through capital markets.

As one of the largest economic power is the influence of the United States for other countries, it also includes the influence of companies and investors. So the movement of the DJIA, which is one of the index in the NYSE (New York Stock 
Exchange) will have no effect on the movement of the other countries. One example in the year 2008 where the current mortgage crisis in the US which finally also drag the IHSG down to $50 \%$, whereas the impact the crisis on the economy of Indonesia is relatively small. It turns out that JCI decline occurred because many fund managers from Europe and the US are experiencing a crisis of liquidity, drawn large - scale by investors so have to sell its portfolio. As investors we should take another look at the fundamentals of the company and its prospects are not tossed about by the movement of the DJIA index. The statement associated with the performance of the Dow Jones in figure 5 as follows.

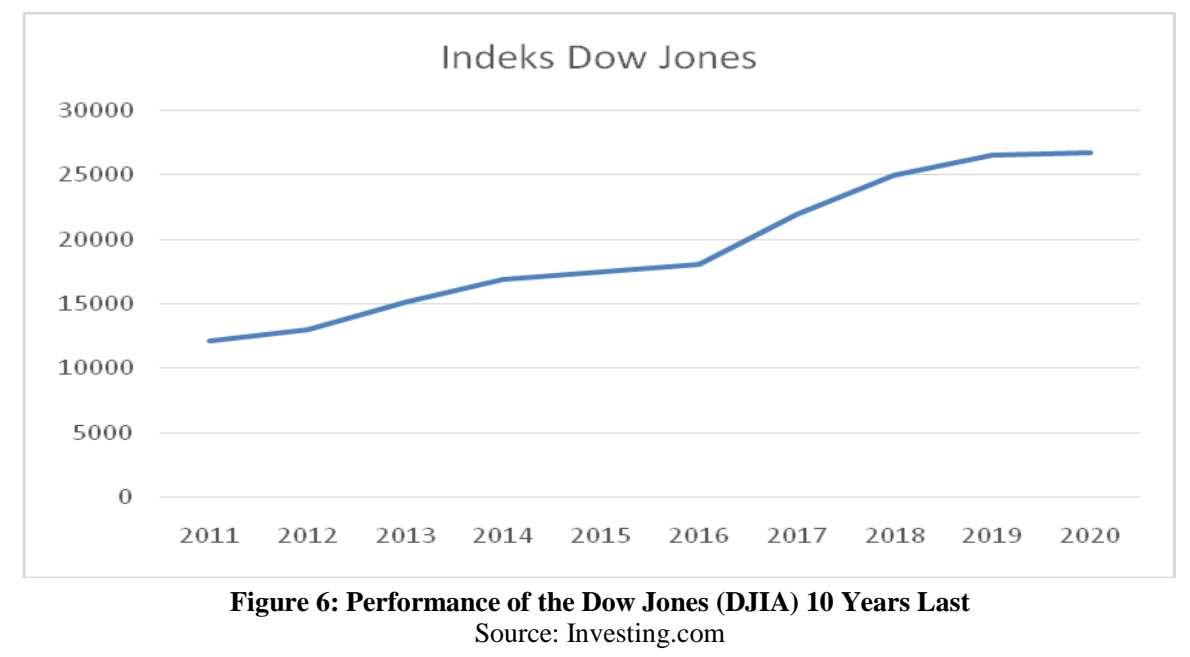

In Figure 6 describes the performance of the last 10 years, where every year the Dow Jones continues to increase from year 2010 the Dow Jones by 10.594,93 until the year 2020 the Dow Jones by $26.709,25$. it is the Dow Jones is a stock market index of the most leading and indices as indicators of market movers of the United States, in addition Dow Jones is a stock of the oldest and most reliable in the United States.

\section{LITERATURE REVIEW The Composite Stock Price Index}

The composite stock price index is the index, a stock price that has been prepared and is calculated by generating a trend, where the figure index is a number that is processed in such a way that it can be used to compare the incidence of which can be in the form of stock price changes from time to time (Jogiyanto, 2013).

\section{Inflation}

Inflation is an important event that gives a negative impact or a positive impact on the economy of a country. Inflation is usually marked by the amount of money in circulation but the purchasing power of the society or the usability of the money is not high (Nurwati, 2016).

\section{Exchange Rate}

The exchange rate is a comparison of the value of the currency when the exchange occurs involving two different currencies. This transaction will cause the supply and demand for a particular currency, here is some understanding regarding the exchange rate. The exchange rate is the price of a currency relative to another country's currency. The exchange rate plays an important role in the decisionmaking spending, because of the exchange rate allows us to translate the prices of the different countries in the same language (Mahyus Ekananda, 2014).

\section{Interest Rates}

Interest rates are the price of the loan the interest rate expressed as a percentage of the principal money per unit of time. Interest is a measure of the price of resources used by the debtor to be paid to 
creditors. In addition to international interest rates, discount rate interest rate (SBI) is also an important factor in the determination of interest rates in Indonesia (Sunariyah, 2013).

\section{The Dow Jones}

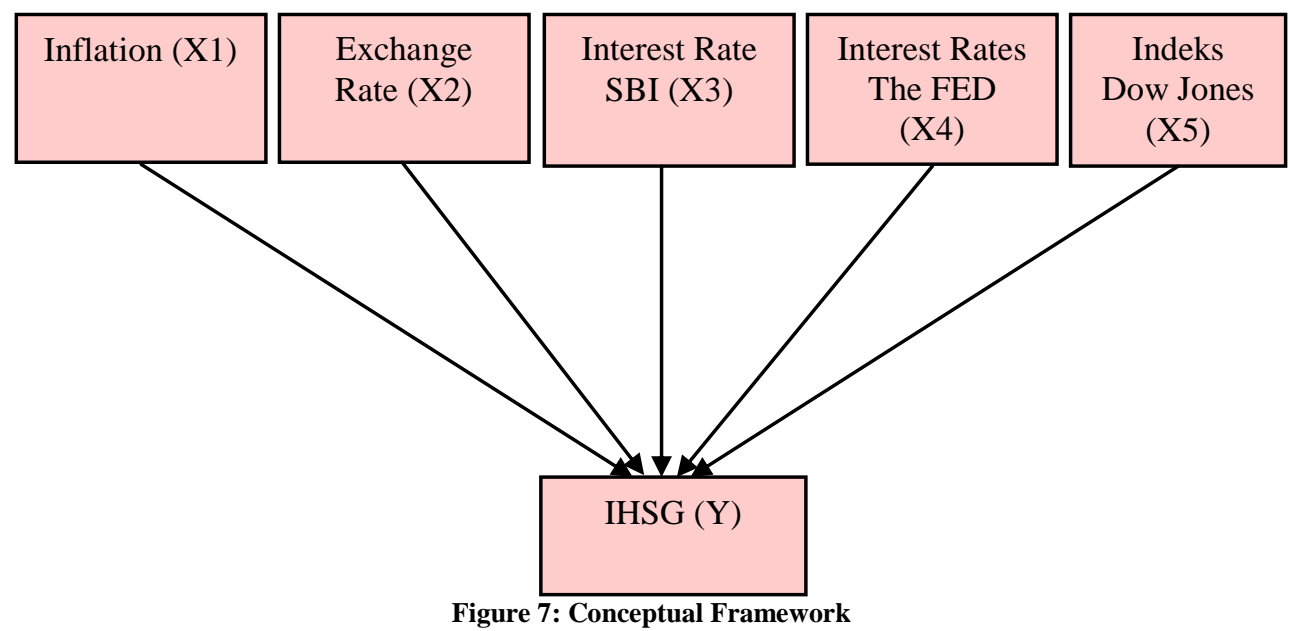

\section{Hypothesis}

Based on the background research and the relationship between variables, then the research hypothesis:

1. Negative effect of inflation to IHSG in BEI.

2. Exchange rate negatively affects the IHSG in BEI.

3. Rate interest of SBI negatively affects the IHSG in BEI.

4. Interest rates the Federal Reserve negatively affect the IHSG in BEI.

5. The Dow Jones has a positive effect on IHSG in BEI.

\section{MATERIAL AND METHODS}

This study uses a quantitative approach. Quantitative research is a method to test certain theories by way of examining the relationship between variables. Variable-variable is measured with the instruments of the study, so that the data consist of the numbers can be analyzed based on the procedures of statistics (Jhon W, 2012). Quantitative research methods can be interpreted as a method of

research based on the philosophy of positivism, is used to examine the
Jones Industrial Average (DJIA) is: "one of the stock market index established by the Editor of the Wall Street Journal and founder of Dow Jones \& Company Charles Dow. Dow make this index as a way to measure the performance of the industrial components in the American stock market (Ardiyan, 2008). 


\section{RESULTS}

\section{Cointegration Test (Bound Test Cointegration)}

Cointegration serve as a tool to analyze and solutions time series data are not stationary, in particular for research with a model of ARDL. The method of cointegration test Bounds Testing Cointegration is used to see the long-term relationship between the variables in the equation.

From Table 3 explains that the results of the cointegration test using the approach of Bound Test shows the Fstatistic of 4,536360 and significant value within $5 \%$ with the value of I(0) Bound by 2.56 and the value of I(1) Bound by 3,49.
The results of the cointegration test ARDL or Bounds testing cointegration show that the value of F-statistic is greater than the value of I (0) Bound and I (1) Bound 5\%. So it can be concluded that there is a cointegration between the variables of the study and can also be said that there is a long-term relationship between the variables of the study.

Table 3: Bound Test Cointegration

\begin{tabular}{|c|c|c|}
\hline \multicolumn{3}{|c|}{ F-statisticValue4.536360 } \\
\hline Significance & $\begin{array}{c}\text { I(0)Bound } \\
\text { (LowerBound) }\end{array}$ & $\begin{array}{c}\text { I(1)Bound } \\
\text { (UpperBound) }\end{array}$ \\
\hline $10 \%$ & 2.2 & 3.09 \\
\hline $5 \%$ & 2.56 & 3.49 \\
\hline $25 \%$ & 2.88 & 3.87 \\
\hline $1 \%$ & 3.29 & 4.37 \\
\hline \multicolumn{3}{|c|}{ Source: Eviews 10 }
\end{tabular}

Test the Estimated Coefficient of the Short-Term and Long-Term

Table 4: Estimation Results of the Model Short-Term Model ARDL

\begin{tabular}{|l|c|c|c|c|}
\hline \multicolumn{1}{|c|}{ Variable } & Coefficient & Std. Error & t-Statistic & Prob. \\
\hline D(LOGKURS) & -1.021835 & 0.195930 & -5.215306 & 0.0000 \\
\hline D(FED) & 0.017640 & 0.028932 & 0.609687 & 0.5464 \\
\hline D(FED(-1)) & 0.145445 & 0.033323 & 4.364648 & 0.0001 \\
\hline D(LOGDJIA) & 0.677696 & 0.080722 & 8.395428 & 0.0000 \\
\hline CointEq(-1)* & -0.387849 & 0.069137 & -5.609902 & 0.0000 \\
\hline \multicolumn{7}{|c|}{ Source: Eviews 10} \\
\hline
\end{tabular}

The results of the test of the estimated coefficient of the short-term in table 4 show that the:

1. Variable exchange rate and a significant negative effect on the IHSG in the short term. It can be seen from the value of the coefficient of $-1,021835$ which indicates a negative value and the probability of exchange by 0,0000 a significant meaning. It can be concluded that in the short term the exchange rate affect the IHSG.

2. Variable interest rates The FED has positive and not significant to the IHSG in the short term. It can be seen from the value of the coefficient of 0,017640 which indicates a positive value and the probability of interest rates The FED's 0,5464 which means not significant, but the level of The FED's benchmark rate of the previous year and significant positive effect on the IHSG in the short term. It can be seen from the value of the coefficient of 0,145445 which indicates a positive value and the probability level of The FED's benchmark rate of 0.0001 . It can be concluded that the level of The FED's benchmark rate of the previous year affect the IHSG in the short term.

3. Variable index Dow Jones and significant positive effect on the IHSG in the short term. It can be seen from the value of the coefficient of 0.677696 which indicates a positive value and the probability of the Dow Jones of 0.0000 which means significant. It can be concluded that the Dow Jones affects the IHSG in the short term.

4. The estimation of the speed of adjustment towards the long-term in the gain coefficient of the ECM on the model. It's important to be reminded in the estimation of the ECM is that the error correction term (ECT) should be negative and significant, a negative value in the ECT indicates that the models in the estimation of the invalid. All the coefficients in the equation of the short-term above is the coefficient 
that connects a dynamic model in the short term converging towards the balance. This shows how the imbalance caused by the shock in the previous adjusted on the balance of the long-term this year. In Table 4 explain the value of the ECM is negative and significant, which $-0,387849$ and the value of significance that is of 0.000 , which means there is a coefficient that connects a dynamic model in the short term towards the balance of long-term, i.e. during a 3.8-quarter.

Here is the test result of the estimated coefficients of the long-term in this study: Table 5: Estimation Results of the Model Long-Term Model ARDL

\begin{tabular}{|l|c|c|c|c|}
\hline \multicolumn{1}{|c|}{ Variable } & Coefficient & Std. Error & t-Statistic & Prob. \\
\hline LOGKURS & -0.413929 & 0.311531 & -1.328690 & 0.1933 \\
\hline SBI & 0.015755 & 0.021673 & 0.726959 & 0.4725 \\
\hline FED & -0.080914 & 0.050037 & -1.617069 & 0.1157 \\
\hline LOGDJIA & 0.913756 & 0.256299 & 3.565202 & 0.0012 \\
\hline C & 3.414211 & 1.090233 & 3.131635 & 0.0037 \\
\hline \multicolumn{5}{|c|}{ Source: Eviews 10 } \\
\hline
\end{tabular}

From the results of the estimation of the long-term use model ARDL in table 5 it can be seen that one of the dependent variables that significantly influences the independent variable.

1. Variable exchange rate and no significant negative effect on the IHSG in the long term. It can be seen from the value of the coefficient of $-0,413929$ which indicates a negative value and the probability value of the exchange rate of 0,1933 which means that it is not significant. It can be concluded that the value of the exchange rate did not significantly affect the IHSG in the long term.

2. Variable interest rate SBI has positive and not significant to the IHSG in the long term. It can be seen from the value of the coefficient of 0,015755 which indicates a positive value and the value of the probability of SBI interest rate of 0.4725 which means that it is not significant. It can be concluded that the level of rates SBI does not significantly affect the IHSG in the long term.
3. The variable interest rates of The FED's negative effect and not significant to the IHSG in the long term. It can be seen from the value of the coefficient of 0,080914 which indicates a negative value and the value of the probability of interest rates The FED's 0,1157 which means not significant. It can be concluded that the level of interest rates The FED does not significantly affect the IHSG in the long term.

4. Variable index Dow Jones and significant positive effect on the IHSG in the long term. It can be seen from the value of the coefficient of 0,913756 which indicates a positive value and the value of the probability of the Dow Jones by 0,0012 which means significant. It can be concluded that the Dow Jones significantly affect the IHSG in the long term.

\section{DISCUSSION Inflation Effect on IHSG}

The hypothesis proposed in this research is "Allegedly negative effect of inflation to IHSG". Based on the results of the calculations obtained the value of the probability not in accordance with the criteria it can be concluded that hypothesis in decline. These results indicate that inflation does not affect directly against the IHSG in both the short and long term. This explains that in the study period the inflation does not directly affect the decision of investors in investing in shares on Indonesia stock exchange. Where inflation is not one of the factors directly into consideration for investors in making investment decisions. Investors are still more likely to wait as well as observing other factors such as changes in the value of the exchange rate, SBI interest rate, The FED's benchmark rate, the global index and the other in the aggregate or whole. Next new investors to take decisions related to investment in Indonesia stock exchange. This means that although inflation increase or decrease will not give effect to the IHSG. Based on inflation data in descriptive 
statistics, the average inflation rate during the study period below $10 \%$, if that's the case then the market can still be received, but when inflation redeem the $10 \%$, then the capital market will be distracted.

The results of this study in accordance with the results of the study Tobing (2009), Pasa thousand (2009), Bin Raudha (2017). Where the results of his research stated that the inflation rate has no significant effect on IHSG. The concept of inflation is the signal negative for investors in the market model because inflation increases the income and expenses of the company. If production costs rise higher and not anticipated by the company, then the impact the decline in the probability of a company. Miskhin (2008:321) states that the theory of portfolio there are factors that affect the demand for securities, including inflation, exchange rate, interest rate, and wealth. However, inflation turns out to not directly into the consideration of the investors in the policy of investing. Investors tend to wait for news of other information, such as the exchange rate, SBI, global interest rates and global indices. Then analyze all the information simultaneously to be used as a material consideration in the decision to invest. The results of the research in inversely proportional to the results of research of $\mathrm{Ni}$ Made (2014), Aditya (2012) where the results of his research stated inflation and a significant negative effect on IHSG.

\section{Exchange Rate Effect on IHSG}

Hypothesis 2, which proposed in this research is "Suspected of the exchange rate (exchange rate of United states Dollar.) negatively affect the IHSG". Based on the results of the calculation shows that hypothesis 2 is proved. Where the rate shows a negative influence in the short term but not for the long term. This suggests that the strengthening of the exchange rate against rupiah will have an impact on the strengthening of the composite stock price index and vice versa. Such a result is consistent with the concept that if the u.s.
Dollar strengthened against the Dollars or the price of the Dollar is expensive then the investor will turn invest his wealth in the form of a Dollar compared to investing in stocks, and foreign companies. In general strengthening of the US Dollar against the rupiah will also have an impact on the company's issuer. Where if the issuer company has a debt in the form of Dollar will increase the burden or losses. So the impact on the decline in profit company, so that investors are hesitant to invest in the stock companies of the issuer are exposed to the negative impact. Investors automatically will choose to invest in the form of Dollars or more. The results of this study are in line with the results of the research Tobing (2009), Aditya (2012), Triyono (2017) where the results of his research stated that the factors are exchange rate USD/IDR significant negative effect on the movement of the composite stock price index. However inversely proportional to the research of M. Noor (2018) where the results of his research stated rate significant positive effect on IHSG.

\section{SBI Interest Rate Affect the IHSG}

Hypothesis 3 is proposed in this research is "Suspected of SBI interest rate have negative effect on IHSG". Based on the results of the calculation shows that the hypothesis 3 is not proven or rejected. The results show changes in interest rates SBI does not have a significant effect on IHSG better in the long run and in the short term. Which can be interpreted SBI is not the main factor that takes into consideration the investors in decision-making in investing in Indonesia stock Exchange. This is expected because of the type of investors in Indonesia are happy to do the transaction the stock in the short term (trader) so that the investor is more often do profit taking with gain capital gain is quite high in the capital market invest in deposits. (Manulang, 2008). Not only that, SBI does not affect the IHSG caused also due to the interest rates of SBI less effective to divert public funds in the form of deposits in the Bank. Less effective 
the policy caused because the Bank did not directly respond to the SBI interest rate hikes by raising the bank rate, better interest rates on deposits and lending interest credit. Not the flow of public funds to the Bank in the form of deposits is expected due to the demand to invest in the form of shares does not change. On the credit side, the company is not charged interest expense bank credit that is high. Due to the increase in interest rates of commercial banks. So the company's financial performance remained stable. Where the company's performance is an indicator that investors attention before make a purchase stock, the granting of the dividends is a stimulus for investors to invest in the capital market. The results of this study are in line with the results of the research Ari (2017), Triyono (2017), where the results of his research stated that the SBI interest rate and no significant negative effect on IHSG. However inversely proportional to the results of the study Manihuruk (2017), Ni Made (2014) where the results of his research interest rates SBI simultaneously significant effect on IHSG.

\section{Interest Rates the FED Affect the IHSG}

Hypothesis 4 proposed in this research is "Allegedly The FED's benchmark rate has a positive effect on IHSG". Based on the results of the calculation shows that the hypothesis 4 is proved. Based on the results, in the shortterm interest rates The Fed has positive and significant effect on the IHSG, but in the long term instead. It means The FED's benchmark rate is one of the main factors that determine investors in investing in the short term. The results of this study aligned with the theory of contangen or called a theory domimo modern, where the influence of foreign economic to be one of the considerations in the decision making for investors in investing in which The FED's benchmark rate, But in the long term theory domimo haven't proven that the foreign economy does not affect the IHSG. This is due to the investor in Indonesia is often invest only for short term transactions only.
This research is in line with the results of the research the results of the research Miyanti (2018) where the results of his research stated that the fed has positive and significant effect o IHSG, But inversely proportional to the Surbakti (2011), and Ryan (2019).

\section{Dow Jones Effect on IHSG}

Hopotesis 5 in the proposed in this study is "Allegedly the Dow Jones has a positive effect on IHSG. Results obtained from the calculation that the hypothesis 5 proven and accepted. This shows in the short term and long-term the Dow Jones responded positively and not significant on the long-term but significant effect on IHSG. This is in line with the theory and some research that stated that the Dow Jones positive effect or unidirectional significantly to the IHSG. Abdul (2008) stated that the Indonesian capital market is integrated with the market capital of the world. This has the impact that the movement of the Indonesian capital market will be influenced by the movement of the capital market of the world in both the short and long term. This research is in line with the research of M. Noor (2018) and Amin (2012). Background because the United States is the country of destination of exports for Indonesia, so that changes in economic conditions of the United States which will be reflected in the Dow Jones will give effect to the Indonesian economy through the IHSG. However inversely proportional to the result of the research Dewanto (2014) which states the Dow Jones have a negative effect and not significant to the IHSG.

\section{CONCLUSIONS AND RECOMMENDATIONS CONCLUSIONS}

Based on the analysis of the description of the discussion that has been described above, the authors can conclude 5 following:

1. Inflation does not affect the IHSG better in the long term, in the short term. From 
the calculation results in long-term inflation negative affect $(-0,021882)$ and significant $(0,2538)$. In the short term inflation effect is negative $(--0,008759)$ and not significant $(0,2476)$.

2. Exchange rate effect on the IHSG, where the value of the exchange rate (exchange rate) negative effect ($0,539757)$ and significant $(0,0027)$ in the short term. Exchange rate (exchange rate) negative effect $(-0,539757)$ and not significant $(0,1094)$ in the long term.

3. SBI interest rate does not affect the IHSG in both the short and long term. Rate bungadalam long-term SBI positive effect $(0,036946)$ but not significant $(0,1984)$, in the short term positive effect $(0,014788)$ and not significant $(0,1937)$,

4. Interest rates The FED period the previous effect against the IHSG, in the short-term interest rates The FED negative effect $(-0,041451)$ and significant $(0,0297)$. On long-term interest rates The FED negative effect $(0,103556)$ and not significant $(0,0688)$.

5. The Dow Jones effect on IHSG both in long and short term investments. In the long term the Dow Jones effect positive $(1,010023)$ and significant $(0,0007)$, in the short term the Dow Jones positive effect $(0,162498)$ and significant $(0,0000)$.

\section{RECOMMENDATIONS}

Suggestions of researchers from the research that has been done is as follows:

1. Should the authority of the macro economy in controlling the stability of the IHSG prioritize on the policy of inflation, exchange rates, the level of interest rates The FED and the Dow Jones. Where all strengthen the control and stability of market shares on the stock exchange.

2. Policies need to improve the IHSG should be based on the external aspect of the economy, that is the exchange rate, the level of interest rates The FED and the Dow Jones where the third variable is the variable that most big influence on the IHSG.

3. For students who want to conduct further research is expected to add an external variable can thus also affect the IHSG, because of which affect the IHSG more than external factors.

4. For the government to pay attention and take the policy to prioritize the domestic economic conditions and still pays attention to foreign economic order to be able to control the composite stock price index.

5. For investors, to perform investment that need to be used as a material consideration in decision-making is a condition of foreign economies, including the United States.

Acknowledgement: None

Conflict of Interest: None

Source of Funding: None

\section{REFERENCE}

1. Abimanyu, A. dan A. Megantara. 2009. Era Baru Kebijakan Fiskal, Pemikiran, Konsep dan Implementasi. Jakarta: Kompas.

2. Adler Haymens Manurung. 2003. Memahami Seluk Beluk Investasi, Jakarta: PT. Adler Manurung.

3. Agus, Sartono. 2012. Manajemen Keuangan Teori dan Aplikasi. Edisi 4. Yogyakarta: BPFE.

4. Ang, Robert. 1997. Buku Pintar Pasar Modal Indonesia (The Intelligent Guide to Indonesian Capital Market). Jakarta: Mediasoft Indonesia.

5. Anoraga, Pandji dan Piji Pakarti. 2001. Pengantar Pasar Modal. Edisi Revisi. Jakarta: PT. Mahasatya.

6. Atmadja, Adwin S., Yanhui Wu, dan Wan Juli. 2009. Market Integration and Financial crisis: New Evidence from Asian Pacific Markets. Indonesia Capital Market Review, 4th Edition, Forthcoming.

7. Boediono. 1998. Ekonomi Moneter, Seri Sinopsis Pengantar Ilmu Ekonomi No.5. Yogyakarta: BPFE UGM.

8. Brigham Eugene, F. dan J. Houston. 2004. Fundamentals of Financial Management Dasar-Dasar Manajemen Keuangan. Edisi 10. Buku 2. Jakarta: Salemba Empat. 
9. Brigham dan Houston. 2010. Dasar-Dasar Manajemen Keuangan Buku 1. Edisi II. Jakarta: Salemba Empat.

10. Dahlan, Siamat, 2005, Manajemen Lembaga Keuangan, Jakarta: Penerbit Fakultas Ekonomi universitas Indonesia.

11. Dornbusch, Rudiger, Stanley Fischer, dan Richard Startz. 2008. Tenth Edition. Macroeconomics. New York: Mc Graw Hill Companies.

12. Ekananda, Mahyus. 2014. Ekonomi Internasional. Jakarta: Erlangga.

13. Engle, Robert F dan Granger C. W. J. 1987. Co-Integration and Error Correction: Representation, Estimation, and Testing. Econometrica. Vol. 55, No. 2. (Mar., 1987), pp. 251-276.

14. Fabozzi, Frank J. 1995. Investment Management. Prentice Hall Inc: New Jersey.

15. Fabozzi, Frank J., Modigliani, Franco, Ferry, Michael G. 1998. Foundation of Financial Market and Institutions. 2nd edition. Prentice Hall: New Jersey.

16. Kotler, Philip. 1990. Manajemen Pemasaran. Jilid I. Edisi Indonesia. Edisi Milenium, Edisi Kesepuluh. Jakarta: PT. Prenhallindo.

17. Ghozali, Imam. 2011. Aplikasi Analisis Multivariate Dengan Program SPSS. Semarang: Badan Penerbit Universitas Diponegoro.

18. Gujarati dan Porter. 2009. Dasar - Dasar Ekonometrika. Jakarta: Salemba Empat.

19. Greg Adams. Grant McQueen dan Robert Wood. 2004. The Effects of Inflation News on High Frequency Stocks Returns. The Journal of Business. Jul 2004. hal. 547-574.

20. Hady, Hamdy. 2010. Ekonomi Internasional, Teori dan Kebijakan Perdagangan Internasional Jilid 2. Jakarta: Ghalia Indonesia.

21. Hartono, Jogiyanto. 2013. Teori Portofolio dan Analisis Investasi. Yogyakarta: BPFE.

22. Haryogo, A. 2013. Pengaruh Nilai Tukar dan Indeks Dow Jones Terhadap Composite Index di Bursa Efek Indonesia.Finesta, 1(1), 1-6.

23. Haug, Roger T. 1993. The Prctical Handbook of Compost Engineering (New York: Lewish Publisher, 1993) hal 546.

24. Hermuningsih, Sri. 2012. Pengantar Pasar Modal Indonesia. Yogyakarta: UPP STIM YKPN.
25. Hidayati, A. 2017. The Effect of BI Rate, World Oil Price, Rupiah Exchange Rate, and Inflation Rate on Jakarta Composite Index at Indonesia Stock Exchange in January 2011-December 2015 Period. Jakarta: Doctoral dissertation Universitas Jenderal Soedirman.

26. Creswell, John W. 2012. Research Design Pendekatan Kualitatif, Kuantitatif, dan Mixed. Yogyakarta: Pustaka Pelajar.

27. Hismendi, A. H., \& Musnadi, S. 2013. Analisis pengaruh nilai tukar, sbi, inflasi dan pertumbuhan gdp terhadap pergerakan indeks harga saham gabungan di bursa efek indonesia. Jurnal Ilmu Ekonomi ISSN, 2302, 0172.

28. Johansen, S. and K. Juselius .1990. Maximum Likelihood Estimation and Inference on Cointegration with Application to the Demand for Money. Oxford Bulletin of Economics and Statistics 52, 169-210.

29. Kieso, Donald E. Jerry J. Weygandt, Terry D. Warfield. 2011. Intermediate Accounting, Volume 1. IFRS Edition. United States of America: Quad/Graphic, Inc.

30. Kasmir. 2010. Pengantar Manajemen Keaungan. Jakarta: Kancana Prenada Media Grub.

31. Krugman. 2000. Ekonomi International Teori dan Kebijakan. Jilid 2. Edisi 5. Jakarta: PT Indeks Kelompok Gramedia.

32. Kusuma, I. P. M. E., \& Badjra, I. B. (2016). Pengaruh Inflasi, JUB, Nilai Kurs Dollar dan Pertumbuhan GDP terhadap IHSG di Bursa Efek Indonesia. E-Jurnal Manajemen, $5(3)$.

33. Lucky Bayu Purnomo. 2012. Rahasia dibalik Pengertian Harga Saham. Jakarta: Elex Media Komputindo PT.

34. Madura, Jeff dan Fox, Roland. 2011. International Financial Management. Boston: Cengage Learning.

35. Mankiw, Gregory N. 2000. Teori Makro Ekonomi, Saduran Nurmawan. Jakarta: Erlangga.

36. Manurung, A. H., Pasaribu, P., \&Tobing, W. R. 2008. Pengaruh Variabel Makroekonomi Terhadap IHSG. Jurnal Keuangan.

37. Maulani, A. Taufiq-SPJ, N.\& Pratikto, I. 2021. Perubahan Lahan Mangrove di Pesisir Muara Gembong, Bekasi, Jawa Barat. Journal of Marine Research, 10(1): 55-63. 
38. Mok, Henry MK. 1993. Causality of Interest Rate, Exchange Rate, and Stock Price ata Stock Market Open and Close in HongKong. Asia Pacific Journal of Management. Vol.X. Hal. 123-129.

39. Muliana, R. 2020. Hubungan InterTemporal Antara Pasar Saham Amerika Serikat Dengan Pasar Saham Di Seluruh Dunia: Etd Unsyiah

40. Nopirin. 2012. Pengantar Ilmu Ekonomi, Makro dan Mikro, Edisi Pertama. Yogyakarta: BPFE.

41. Nurbaeti, K. 2010. Pengaruh Aksi Jual Beli Asing, Kurs, SBI, Inflasi, PDB Dan Ideks Hang Seng Terhadap Indeks Harga Saham Gabungan Di Bursa Efek Indonesia Dengan Model GARCH. Jurnal Ilmu Ekonomi: 23-54.

42. Nofiatin, I. 2013. Hubungan Inflasi, Suku Bunga, Produk Domestik Bruto, Nilai Tukar, Jumlah Uang Beredar, dan Indeks Harga Saham Gabungan (IHSG) Periode 2005-2011. Jurnal Aplikasi Manajemen, 11(2): 215-222.

43. Novianto, A., \& Nugroho Sbm, N. S. 2011. Analisis Pengaruh Nilai Tukar (Kurs) Dolar Amerika/Rupiah (US \$/Rp), Tingkat Suku Bunga Sbi, Inflasi, dan Jumlah Uang Beredar (M2) terhadap Indeks Harga Saham Gabungan (IHSG) di Bursa Efek Indonesia (Bei) Periode 1999.1-2010.6. Doctoral dissertation. Universitas Diponegoro.

44. Pesaran, M.H., Shin, Y. \& Smith, R.J. 2001. Bounds testing approaches to the analysis of level relationships. Journal of applied econometrics, 16(3): pp.289-326.

45. Putri, F. L. 2017. Pengaruh Pembiayaan Mudharabah Terhadap Profitabilitas Bank Syariah. Jurnal Pendidikan Akuntansi dan Keuangan, 5(1): 11-18.

46. Rahmawati, D.A Dwi dan Wahyu Hidayat R. 2017. Analisis Pengaruh Suku Bunga Sertifikat Bankindonesia Dan Jumlah Uang Beredar Terhadap Tigkat Inflasi Di Indonesia Periode 200.1-2015.12 (Pendekatan Erroe Crosection Model). Jurnal Ilmu Ekonomi Vol. 1 Jilid 1. hal.6074.

47. Rahardja Prathama, dan Manurung, Mandala. 2000. Teori Ekonomi Mikro Suatu Pengantar. Edisi Kedua. Jakarta: Fakultas Ekonomi Universitas Indonesia.

48. Rahardja Prathama, dan Manurung, Mandala. 2006. Teori Ekonomi Mikro Suatu Pengantar, Edisi Ketiga, Jakarta; Lembaga
Penerbit Fakultas Ekonomi Universitas Indonesia.

49. Renaningtyas, O. \& ST, M. 2018. Editors: Doddy Aditya Iskandar, MeRSA., Ph. D. In Proceedings of the international conference held in Yogyakarta Between (Vol. 26, No. 27).

50. Reilly, Brown. 1997. Investment Analysis and Portfolio Management. 5th ed: The Dryden Press.

51. Sadono, Sukirno. 2011. Makro Ekonomi Teori Pengantar. Jakarta: PT. Rajagrafindo Persada.

52. Samuelson, Paul A. dan William, D. Nordhaus. 1993. Mikro Ekonomi. Terjemahan Drs. Haris Munandar DKK. Edisi ke-14. Jakarta: Erlangga.

53. Samsul. 2006. Pasar Modal dan Manajemen Portofolio. Jakarta: Erlangga.

54. Sangkyun, Park. 1997. Rationality of negative Stock Price Responses to Strong Economics Activity. Journal Financial Analyst. Sept/Oct 1997.

55. Sarono, D. Y. (2014). Pengaruh Inflasi, Tingkat Suku Bunga SBI Dan Nilai Tukar Dollar Terhadap Harga Saham Properti Yang Terdaftar Dalam LQ 45 Di Bursa Efek Indonesia. Surakarta: Doctoral dissertation, Universitas Muhammadiyah.

56. Salim, M. N., \& Hariandja, N. M. 2018. Factors Affecting Joint Stock Price Index (CSPI) And The Impact of Foreign Capital Investment (PMA) Period 2009 To 2016. Humanities and Social Sciences Letters. 6(3): 93-105.

57. Salvatore, Dominick. 2005. Ekonomi Manajerial dalam Perekonomian Global. Jakarta: Salemba Empat.

58. Sihombing, D. 2009. Analisis Pengaruh Faktor Produktivitas Tenaga Kerja Di Kabupaten Dairi, Provinsi Sumatera Utara 1993-2003. Jurnal Kependudukan Indonesia. 4(1): 1-13.

59. Sugiyono. 2013. Metode Penelitian Pendidikan Pendekatan Kuantitatif, Kualitatif, dan R\&D. Bandung: Alfabeta.

60. Sunariyah. 2006. Pengantar Pengetahuan Pasar Modal, Edisi 5. Yogyakarta: UPP AMP YKPN.

61. Sunariyah. 2013. Pengantar Pengetahuan Pasar Modal (Edisi 6). Yogyakarta: UPP STIM YKPN.

62. Sutanto, B. Murhadi, W. R., \& Ernawati, E. (2013). Analisis Pengaruh Ekonomi Makro, Indeks Dow Jones, Dan Indeks Nikkei 225 
Terhadap Indeks Harga Saham Gabungan (Ihsg) Di Bei Periode 2007-2011. Calyptra, 2(1), 1-9.

63. Samsul, Muhamad. 2006. Pasar Modal Dan Manajemen Portofolio. Surabaya: Penerbit Erlangga.

64. Sudarsana, N. M. A. D., \& Candraningrat, I. R. 2014. Pengaruh Suku Bunga SBI, Nilai Tukar, Inflasi Dan Indeks Dow Jones Terhadap Indeks Harga Saham Gabungan Di BEI. E-Jurnal Manajemen. 3(11).

65. Tanjung A. A., Afifuddin, S., Daulay, M., and Ruslan, D. (2017). Relationship Between Monetary Policy, Fiscal, Country Risk, and Macroeconomic Variable in Indonesia. International Journal of Economic Research, 14(15), 207-220.

66. Tanjung, A. A., Daulay, M., Irsad, I., \& Ruslan, D. (2019). The impact of monetary and fiscal policy on poverty in Indonesia. Journal of Applied Economic Sciences, XIV(4(66)), 1068-1073. https://doi.org/ 10.14505/jaes.v14.4(66).12

67. Tanjung A. A. (2021). Bank Lending Channel of Monetary Policy Transmission: New Evidence From Indonesia. ICONS 2020, November 30, Tegal, Indonesia DOI 10.4108/eai.30-11-2020.2303764

68. Tandelilin, E. 2010. Portofolio dan Investasi: Teori dan Aplikasi (1st ed.). Yogyakarta: Kanisius.

69. Tia Nugraha, A. Analisis Pengaruh SBI, Kurs Rupiah, Harga Emas Dunia, Indeks
Hang Seng dan Indeks Nikkei 225 terhadap Indeks Harga Saham Gabungan (IHSG) (studi kasus Bursa Efek Indonesia (BEI) Periode 2008-2011).

70. Triyono, D. 2017. The Effect of Foreign Stock Indexes and Indonesia's Macroeconomics Variables Toward Jakarta Composite Stock Price Index (JCI). Advanced Science Letters. 23(8): 72117214.

71. Utami \& Rahayu, 2003, Peranan Profitabilitas, Suku Bunga, Inflasi, dan Nilai Tukar dalam Mempengaruhi Pasar Modal Indonesia Selama Krisis Ekonomi, Jurnal Manajemen \& Kewirausahaan. Vol. 5, No.2, September 2003:123-131.Surabaya: Ubaya.

72. Yohannes, Y. 2018. Pengaruh Struktur Kepemilikan Terhadap Kebijakan Dividen Pada Perusahaan Terdaftar Di Lq 45 Tahun 2013-2016. Jakarta: Doctoral Dissertation Universitas Mercu Buana Jakarta.

73. http://meiputribersama.blogspot.com/2013/0 6/indeks-harga-saham-gabungan.html

How to cite this article: Sihombing IR, Irsad, Tanjung AA. Analysis of the effect of macro economic indicators and Dow Jones index on IDX Composite in Indonesia Stock Exchange. International Journal of Research and Review. 2021; 8(9): 294-310. DOI: https://doi.org/10. 52403/ijrr.20210940 